\title{
THE WOODY VEGETATION OF QUARTZITE SOILS IN A MOUNTAIN LANDSCAPE IN THE ATLANTIC FOREST DOMAIN (SOUTH-EASTERN BRAZIL): STRUCTURE, DIVERSITY AND IMPLICATIONS FOR CONSERVATION
}

\author{
J. H. C. Ribeiro ${ }^{1}$, C. R. Fonseca ${ }^{1,2}$ \& F. A. Carvalho ${ }^{1,3}$
}

\begin{abstract}
The Serra Negra belongs to the Mantiqueira mountain complex, Minas Gerais, Brazil. It has a vegetation mosaic dominated by ombrophilous and seasonal forest and grassland formations. Woody physiognomies occur on patches of quartzite soils. The aim of the present study was to investigate the patterns of structure and diversity of woody vegetation on quartzite soils in Serra Negra. Ten plots $(20 \times 50 \mathrm{~m})$ were randomly placed in patches of woody vegetation on quartzite soils along the landscape. The diameter and height of all woody plants with a diameter of $\geq 3 \mathrm{~cm}$ at $30 \mathrm{~cm}$ from the soil were measured. The 1899 individuals sampled represented 30 plant families and 68 species. A strong ecological dominance was found, with about $30 \%$ of individuals belonging to a single species, Eremanthus incanus (Asteraceae). The Shannon diversity index $\left(H^{\prime}\right)$ was 2.74 nats/individual and evenness $(J) 0.65$. The two most abundant and ecologically important species in this vegetation type, Eremanthus incanus and Eremanthus erythropappus, called 'candeias', are exploited in the region, mainly for firewood. This exploitation, combined with other factors (e.g. increased tourism), can pose risks to the conservation of the whole flora of the region.
\end{abstract}

Keywords. Atlantic Forest ecosystems, high-altitude rocky complex, multistemmed individuals, scrub.

\section{INTRODUCTION}

Tropical mountains harbour a wide biological diversity, especially with regard to flora (Martinelli, 2007). An important factor governing plant diversity in tropical mountains is the high heterogeneity of environments found in these regions, which leads to the occurrence of species with different adaptations in small areas (Ribeiro et al., 2007). This shows that high beta diversity (Whittaker et al., 2001) is an important component of such systems.

1 Pós-graduação em Ecologia, Instituto de Ciências Biológicas, Universidade Federal de Juiz de Fora, 36036-900, Juiz de Fora, Minas Gerais, Brazil. E-mail for correspondence: jhugocampos@gmail.com

2 Instituto Federal de Educação, Ciência e Tecnologia do Sudeste de Minas Gerais, 38080-001, Juiz de Fora, Minas Gerais, Brazil.

3 Departamento de Botânica, Instituto de Ciências Biológicas, Universidade Federal de Juiz de Fora, 36036900, Juiz de Fora, Minas Gerais, Brazil. 
A characteristic formation occurring in the mountains of south-eastern Brazil is the campos rupestres (rocky grasslands). This vegetation occurs on rocky outcrops and shallow soils, on the tops of mountains, associated with quartzites and sandstones (Benites et al., 2007). It consists of a mosaic of vegetation types, ranging from open areas covered by herbaceous vegetation to areas of dense vegetation mainly comprising shrubs and small trees (Benites et al., 2007; Vasconcelos, 2011; Conceição et al., 2016). The Serra Negra, a component of the Mantiqueira mountain complex, has a vegetation mosaic in which patches of rain forest and campos rupestres predominate in the landscape. A floristic survey of the Serra Negra region has demonstrated its high species richness on a regional scale, with 1020 phanerogamic species (Salimena et al., 2013), 209 pteridophyte species (Souza et al., 2012) and 93 bryophyte species (Amorim, 2013) catalogued so far. Many of these species are considered rare or endemic, and some are endangered. Species new to science, in the process of description, and new botanical records for the state of Minas Gerais have also been found (Salimena et al., 2013).

The area of occurrence of campos rupestres is still a matter of discussion. Most authors agree that campos rupestres occur in the south-east of Brazil, principally in the transition between the Cerrado and Atlantic Forest Domains, in the Espinhaço Range, and other isolated areas (Benites et al., 2007; Vasconcelos, 2011; Alves et al., 2014; Fernandes, 2016). However, there is no consensus about the occurrence of campos rupestres in areas of the Mantiqueira mountain complex, such as Serra Negra and Ibitipoca, both in Minas Gerais State. Although Salimena et al. (2013) considered the open vegetation in Serra Negra to be campos rupestres similar to those encountered at Ibitipoca, Alves et al. (2014) point out that a woody scrub replaces the open vegetation in most parts of the Serra Negra.

The woody scrub highlighted by Alves et al. (2014) in the Serra Negra remains a poorly sampled formation. At present, there is no published work focusing specifically on this formation. Therefore, a specific study on the appropriate methodology for sampling woody plants is necessary. In this paper, we present the first analysis of the structure and diversity of non-forest woody vegetation on quartzite soils in this region of the Mantiqueira mountain complex, Minas Gerais State, Brazil.

\section{Materials AND Methods}

\section{Study area}

The Serra Negra is located between the municipalities of Rio Preto, Lima Duarte, Santa Barbara do Monte Verde and Olaria, at approximately $21^{\circ} 58^{\prime} 43.95^{\prime \prime} \mathrm{S}$, $43^{\circ} 52^{\prime} 16.85^{\prime \prime} \mathrm{W}$ (Fig. 1), and is part of the Mantiqueira mountain complex (Valente et al., 2011). The elevation is $900-1698 \mathrm{~m}$, mean annual temperature is $19.3^{\circ} \mathrm{C}$ and annual mean rainfall is $1886 \mathrm{~mm}$ (EMATER, 2003). The climate is $\mathrm{Cwb}$, according to Köppen's classification (Peel et al., 2007): humid mesothermal with dry and cold winters, and mild and humid summers. 


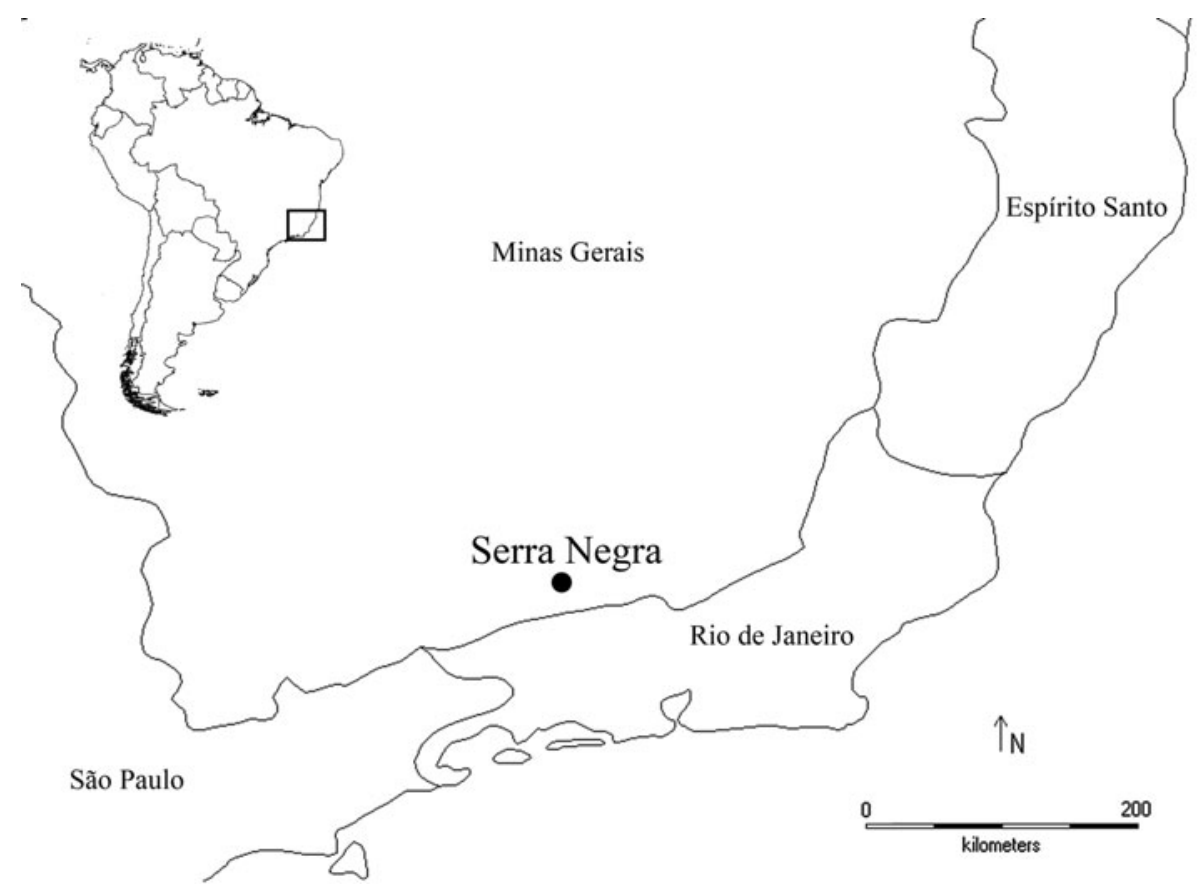

FIg. 1. Location of Serra Negra in the Atlantic Forest Domain, between the municipalities of Rio Preto, Lima Duarte, Santa Barbara do Monte Verde and Olaria, Minas Gerais, in the south-eastern region of Brazil.

The landscape is mountainous, with steep slopes and valleys (Heilbron et al., 2000). The predominant geological formation of the area belongs to the Andrelândia Group, with dystrophic yellow oxisol, in addition to the presence of sand material (quartzite) with low natural fertility (Olszevski et al., 2008; Oliveira \& Marques-Neto, 2014). The quartzites occur as two rock types in the region: coarse quartzite, with $>95 \%$ of quartz grains ranging from 3 to $8 \mathrm{~mm}$ (covering about $28 \mathrm{~km}^{2}$ ), and impure quartzite, that is, quartz associated with feldspar and traces of muscovite, with grains between 1 and 3 $\mathrm{mm}$ (covering about $10 \mathrm{~km}^{2}$ ) (Uagoda et al., 2011).

The region is within the domain of the Atlantic Forest, with a mosaic of vegetation types consisting of forest, shrub and anthropogenic physiognomies. Forest types are described according to the Brazilian vegetation classification (IBGE, 2012) as Alluvial, Montane and Upper Montane Dense Rain Forests (Valente et al., 2011) and Semideciduous Seasonal Forests. The campo rupestre physiognomy occurs mainly on the ridges, associated with quartzites (Salimena et al., 2013). The non-forest woody formations (Fig. 2) that are the target of this study have developed on sandy soils of quartzite origin (coarse quartzite), being distributed across the landscape in patches among other physiognomies. These formations have been described as 'broadleaved 

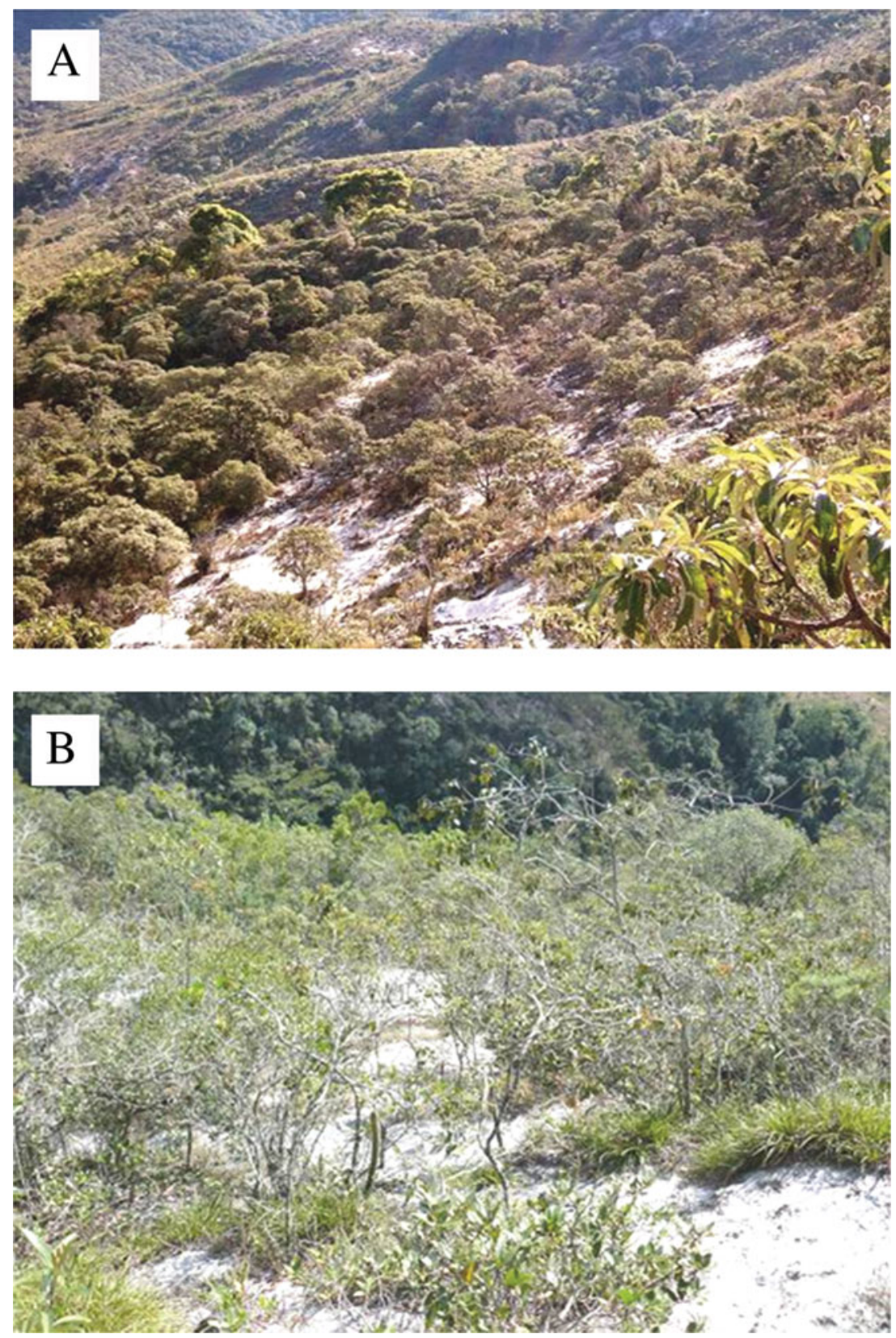

FIG. 2. Woody formations on quartzite soils in Serra Negra, Minas Gerais, Brazil. A, Vegetation mosaic with patches of rain forest and the woody formations occurring on quartzite soils. B, The woody formations that were the target of this study. 
scrubs' by Salimena et al. (2013) following the classification system proposed by Oliveira-Filho (2009), which also corresponds to 'scrub' according to Eiten (1979).

\section{Sampling and data collection}

The sampling methodology was proposed for woody vegetation in grasslands (wood savannas) and rock vegetation types of central and north-eastern Brazil (Felfili et al., 2005). Using the maps provided by Uagoda et al. (2011) and satellite images, 10 patches of non-forest woody formations were randomly selected. In each selected patch, a plot of $20 \times 50 \mathrm{~m}$ was placed in the centre of the area, in order to avoid edge effects. The 10 plots together covered 1 ha. Field data were collected between June and September 2012.

All individuals with a diameter $\geq 3 \mathrm{~cm}$ at $30 \mathrm{~cm}$ above ground level (diameter at ground height) were measured. The height of these individuals was estimated by comparison with a graduated rod. A digital caliper was used to measure the stem diameter (diameter at ground height). Botanical material was collected for identification at species level. Identification of botanical material was made by reference to the literature, consultation with experts and comparison with material deposited in the herbarium Leopoldo Krieger (CESJ) (code following Thiers, continuously updated) of the Federal University of Juiz de Fora. The names of the species and botanical synonyms were confirmed by consulting the Flora do Brasil 2020 (Rio de Janeiro Botanical Garden, continuously updated), and the classification of botanical families followed APG III (Angiosperm Phylogeny Group, 2009).

\section{Data analysis}

For the structural analysis, the following phytosociological parameters of species were evaluated according to formulas described in Kent \& Coker (1992): absolute and relative frequency ( $A F$ and $R F$, respectively); absolute and relative density ( $A D$ and $R D$, respectively); absolute and relative dominance ( $A D o$ and $R D o$, respectively); and importance value ( $I V)$, calculated as the sum of $R F, R D$ and $R D o$. To analyse dominance in multistemmed individuals (individuals that had two or more stems branching below $30 \mathrm{~cm}$ ), we summed the basal areas of each stem (Felfili et al., 2005). The Shannon diversity index $\left(H^{\prime}\right)$ was used in the natural logarithmic base (e) to estimate species diversity. By using a logarithmic basis, this index is more suitable for communities in which species abundance is very uneven, balancing the weight of dominant species (Magurran, 2004). The evenness index $(J)$ based on $H^{\prime}$ was used to estimate the community uniformity. The analyses were performed using the PAST software, version 2.08 (Hammer, 2011).

Histograms of diameter distribution for the community were developed. The class intervals were defined by the approximation of Spiegel's formula (Felfili \& Resende, 2003), resulting in class intervals of $2 \mathrm{~cm}$. Logarithmic fit, its equation and coefficient 


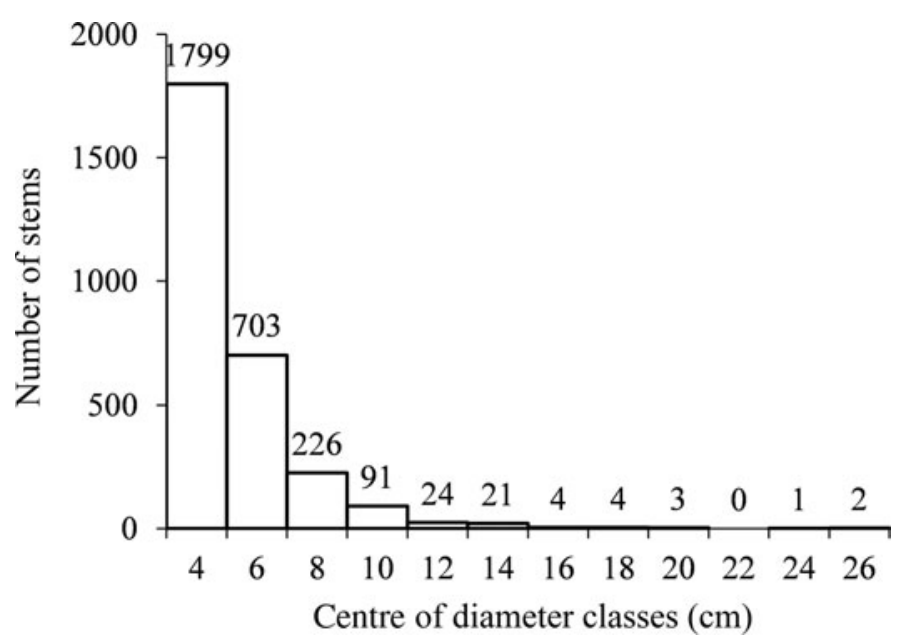

FIG. 3. Frequency distribution in diameter classes of stems in vegetation on quartzite soils in Serra Negra, Rio Preto, Minas Gerais. Logarithmic fit, $R^{2}=0.751$.

of correlation $\left(R^{2}\right)$ for each distribution, was determined. A histogram of height distribution for the community was also prepared, using the class interval of $0.5 \mathrm{~m}$.

\section{RESULTS}

\section{Richness and diversity}

In total, 1899 individuals were sampled, with a mean of $287.9 \pm 50.9$ individuals/plot, belonging to 30 families and 68 species (see Appendix). Six taxa were identified to genus level and three to family level; one was not identified. The family with the largest number of species was Myrtaceae (16 species), followed by Asteraceae and Melastomataceae (five species each) and Lauraceae and Primulaceae (four species each). Annonaceae, Ericaceae, Euphorbiaceae, Fabaceae, Hypericaceae, Lamiaceae, Rubiaceae and Sapindaceae had two species each. All other families were represented by a single species. The Shannon diversity index $\left(H^{\prime}\right)$ was 2.74 nats/individual, and evenness $(J)$ was 0.65 .

\section{Phytosociology and vegetation structure}

Table 1 shows the phytosociological parameters of the community. As observed in the diversity values $\left(H^{\prime}\right.$ and $\left.J\right)$, the results show a community with strong ecological dominance, in which $>50 \%$ of $I V$ is concentrated only in five species: Eremanthus incanus (Less.) Less., Eremanthus erythropappus (DC.) MacLeish, Eugenia modesta DC., Byrsonima variabilis A.Juss. and Trembleya parviflora (D.Don) Cogn.

As seen in Figure 3, most individuals are concentrated in the smaller classes of diameter, gradually decreasing in the bigger classes, in a reverse $\mathbf{J}$ pattern (logarithmic 
TABLE 1. Phytosociological parameters of species sampled in vegetation on quartzitic soils in Serra Negra, Rio Preto, Minas Gerais*

\begin{tabular}{|c|c|c|c|c|c|c|c|}
\hline Species & $A D$ & $A D o\left(\mathrm{~m}^{2}\right)$ & $A F$ & $R D(\%)$ & $R D o(\%)$ & $R F(\%)$ & $I V$ \\
\hline Eremanthus incanus & 543 & 2.0454 & 7 & 28.59 & 29.70 & 5.04 & 63.33 \\
\hline Eremanthus erythropappus & 203 & 1.3874 & 8 & 10.69 & 20.14 & 5.76 & 36.59 \\
\hline Eugenia modesta & 197 & 0.6171 & 7 & 10.37 & 8.96 & 5.04 & 24.37 \\
\hline Byrsonima variabilis & 159 & 0.4204 & 6 & 8.37 & 6.10 & 4.32 & 18.79 \\
\hline Trembleya parviflora & 113 & 0.3724 & 2 & 5.95 & 5.41 & 1.44 & 12.80 \\
\hline Pseudobrickellia angustissima & 85 & 0.2584 & 2 & 4.48 & 3.75 & 1.44 & 9.67 \\
\hline Aspidosperma olivaceum & 61 & 0.1141 & 5 & 3.21 & 1.66 & 3.60 & 8.47 \\
\hline Erythroxylum amplifolium & 63 & 0.2407 & 2 & 3.32 & 3.49 & 1.44 & 8.25 \\
\hline Ocotea tristis & 50 & 0.1153 & 5 & 2.63 & 1.67 & 3.60 & 7.90 \\
\hline Myrcia pulchra & 37 & 0.1496 & 4 & 1.95 & 2.17 & 2.88 & 7.00 \\
\hline Agarista glaberrima & 48 & 0.1666 & 2 & 2.53 & 2.42 & 1.44 & 6.39 \\
\hline Myrcia splendens & 32 & 0.0743 & 5 & 1.69 & 1.08 & 3.60 & 6.36 \\
\hline Matayba marginata & 41 & 0.0802 & 4 & 2.16 & 1.16 & 2.88 & 6.20 \\
\hline Eugenia involucrata & 21 & 0.0341 & 6 & 1.11 & 0.49 & 4.32 & 5.92 \\
\hline Ouratea semiserrata & 20 & 0.0764 & 4 & 1.05 & 1.11 & 2.88 & 5.04 \\
\hline Clusia criuva & 21 & 0.0803 & 3 & 1.11 & 1.17 & 2.16 & 4.43 \\
\hline Myrcia hartwegiana & 15 & 0.0636 & 3 & 0.79 & 0.92 & 2.16 & 3.87 \\
\hline Myrsine umbellata & 15 & 0.0542 & 3 & 0.79 & 0.79 & 2.16 & 3.74 \\
\hline Blepharocalyx salicifolius & 29 & 0.0394 & 2 & 1.53 & 0.57 & 1.44 & 3.54 \\
\hline Tibouchina fissinervia & 21 & 0.0837 & 1 & 1.11 & 1.22 & 0.72 & 3.04 \\
\hline Tibouchina estrellensis & 7 & 0.0174 & 3 & 0.37 & 0.25 & 2.16 & 2.78 \\
\hline Persea rufotomentosa & 4 & 0.0303 & 2 & 0.21 & 0.44 & 1.44 & 2.09 \\
\hline Chamaecrista cathartica & 6 & 0.0210 & 2 & 0.32 & 0.30 & 1.44 & 2.06 \\
\hline Ternstroemia brasiliensis & 6 & 0.0112 & 2 & 0.32 & 0.16 & 1.44 & 1.92 \\
\hline Lamanonia cuneata & 9 & 0.0484 & 1 & 0.47 & 0.70 & 0.72 & 1.90 \\
\hline Maytenus urbaniana & 4 & 0.0049 & 2 & 0.21 & 0.07 & 1.44 & 1.72 \\
\hline Guatteria australis & 2 & 0.0059 & 2 & 0.11 & 0.09 & 1.44 & 1.63 \\
\hline Myrsine lancifolia & 2 & 0.0027 & 2 & 0.11 & 0.04 & 1.44 & 1.58 \\
\hline Myrcia venulosa & 2 & 0.0016 & 2 & 0.11 & 0.02 & 1.44 & 1.57 \\
\hline Clethra scabra & 2 & 0.0015 & 2 & 0.11 & 0.02 & 1.44 & 1.57 \\
\hline Alchornea triplinervia & 3 & 0.0427 & 1 & 0.16 & 0.62 & 0.72 & 1.50 \\
\hline Vismia magnoliifolia & 7 & 0.0262 & 1 & 0.37 & 0.38 & 0.72 & 1.47 \\
\hline Myrcia guianensis & 8 & 0.0150 & 1 & 0.42 & 0.22 & 0.72 & 1.36 \\
\hline Myrsine gardneriana & 4 & 0.0174 & 1 & 0.21 & 0.25 & 0.72 & 1.18 \\
\hline Myrcia mutabilis & 5 & 0.0123 & 1 & 0.26 & 0.18 & 0.72 & 1.16 \\
\hline Seguieria sp. & 1 & 0.0250 & 1 & 0.05 & 0.36 & 0.72 & 1.13 \\
\hline Macropeplus schwackeanus & 5 & 0.0097 & 1 & 0.26 & 0.14 & 0.72 & 1.12 \\
\hline Tapirira obtusa & 1 & 0.0241 & 1 & 0.05 & 0.35 & 0.72 & 1.12 \\
\hline Pera glabrata & 4 & 0.0122 & 1 & 0.21 & 0.18 & 0.72 & 1.11 \\
\hline Hyptis monticola & 5 & 0.0049 & 1 & 0.26 & 0.07 & 0.72 & 1.05 \\
\hline Gaylussacia densa & 4 & 0.0069 & 1 & 0.21 & 0.10 & 0.72 & 1.03 \\
\hline Undetermined sp. 1 & 2 & 0.0120 & 1 & 0.11 & 0.17 & 0.72 & 1.00 \\
\hline Eugenia sp. & 3 & 0.0044 & 1 & 0.16 & 0.06 & 0.72 & 0.94 \\
\hline Eugenia bimarginata & 2 & 0.0078 & 1 & 0.11 & 0.11 & 0.72 & 0.94 \\
\hline Ladenbergia hexandra & 1 & 0.0080 & 1 & 0.05 & 0.12 & 0.72 & 0.89 \\
\hline
\end{tabular}


TABLE 1. (Continued)

\begin{tabular}{llllllll}
\hline \hline Species & $A D$ & $A D o\left(\mathrm{~m}^{2}\right)$ & $A F$ & $R D(\%)$ & $R D o(\%)$ & $R F(\%)$ & $I V$ \\
\hline Calea sp. & 2 & 0.0019 & 1 & 0.11 & 0.03 & 0.72 & 0.85 \\
Vismia parviflora & 2 & 0.0018 & 1 & 0.11 & 0.03 & 0.72 & 0.85 \\
Eugenia handroana & 2 & 0.0018 & 1 & 0.11 & 0.03 & 0.72 & 0.85 \\
Miconia sp. 1 & 1 & 0.0051 & 1 & 0.05 & 0.07 & 0.72 & 0.85 \\
Fabaceae sp. 1 & 1 & 0.0041 & 1 & 0.05 & 0.06 & 0.72 & 0.83 \\
Cabralea canjerana & 1 & 0.0027 & 1 & 0.05 & 0.04 & 0.72 & 0.81 \\
Xylopia brasiliensis & 1 & 0.0026 & 1 & 0.05 & 0.04 & 0.72 & 0.81 \\
Maprounea guianensis & 1 & 0.0026 & 1 & 0.05 & 0.04 & 0.72 & 0.81 \\
Pavonia viscosa & 1 & 0.0021 & 1 & 0.05 & 0.03 & 0.72 & 0.80 \\
Persea willdenovii & 1 & 0.0018 & 1 & 0.05 & 0.03 & 0.72 & 0.80 \\
Remijia ferruginea & 1 & 0.0017 & 1 & 0.05 & 0.03 & 0.72 & 0.80 \\
Vitex sellowiana & 1 & 0.0014 & 1 & 0.05 & 0.02 & 0.72 & 0.79 \\
Miconia urophylla & 1 & 0.0013 & 1 & 0.05 & 0.02 & 0.72 & 0.79 \\
Psidium firmum & 1 & 0.0012 & 1 & 0.05 & 0.02 & 0.72 & 0.79 \\
Handroanthus albus & 1 & 0.0012 & 1 & 0.05 & 0.02 & 0.72 & 0.79 \\
Myrtaceae sp. 1 & 1 & 0.0011 & 1 & 0.05 & 0.02 & 0.72 & 0.79 \\
Lauraceae sp. 1 & 1 & 0.0010 & 1 & 0.05 & 0.01 & 0.72 & 0.79 \\
Myrsine sp. 1 & 1 & 0.0009 & 1 & 0.05 & 0.01 & 0.72 & 0.78 \\
Cupania ludowigii & 1 & 0.0008 & 1 & 0.05 & 0.01 & 0.72 & 0.78 \\
Eugenia sp. 2 & 1 & 0.0008 & 1 & 0.05 & 0.01 & 0.72 & 0.78 \\
Ilex subcordata & 1 & 0.0008 & 1 & 0.05 & 0.01 & 0.72 & 0.78 \\
Verbesina pseudoclaussenii & 1 & 0.0008 & 1 & 0.05 & 0.01 & 0.72 & 0.78 \\
Eugenia widgrenii & 1 & 0.0007 & 1 & 0.05 & 0.01 & 0.72 & 0.78 \\
Total & 1899 & 6.8872 & 139 & 100 & 100 & 100 & 300 \\
\hline \hline Species order by & & & & & & & \\
\hline
\end{tabular}

*Species ordered by decreasing importance value $(I V=R D+R D o+R F)$.

$A D$, absolute density; $A D o$, absolute dominance; $A F$, absolute frequency; $R D$, relative density; $R D o$, relative dominance; $R F$, relative frequency.

fit, $\left.y=-608 \ln (x)+1253 ; R^{2}=0.751\right)$. The same pattern was observed when the biomass (sum of basal areas of individuals) was analysed by diameter class, showing that the major fraction of biomass is accumulated in smaller individuals (Fig. 4; logarithmic fit, $\left.y=-0.96 \ln (x)+2.172 ; R^{2}=0.920\right)$.

The distribution of individuals in height classes shows that the community is characterised by a large number of small individuals, with some emergents reaching a maximum height of $6 \mathrm{~m}$ (Fig. 5). It is not possible to identify the formation of different strata. Furthermore, the vegetation is not continuous, occurring more densely at some sites and sparsely at others, even at small scales (Fig. 2).

Another important aspect is the large number of multistemmed individuals (Table 2), with about $28 \%$ of individuals multistemmed at ground height $(30 \mathrm{~cm}$ above ground), and $48.5 \%$ of species with at least one multistemmed individual. Of the species with highest density (more than 10 individuals), only one, Tibouchina fissinervia (Schrank \& Mart. ex DC.) Cogn. (species name listed in Flora do Brasil 2020, Rio de Janeiro Botanical Garden, continuously updated; Tibouchina fissinervia Cogn. in the 


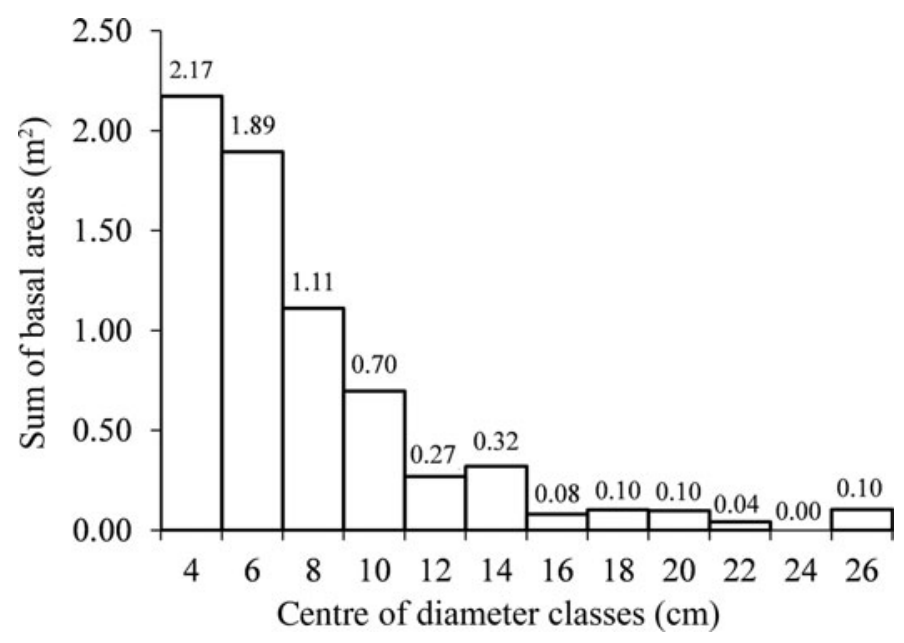

FIG. 4. Sum of basal areas per diameter class for vegetation on quartzite soils in Serra Negra, Rio Preto, Minas Gerais. Logarithmic fit, $R^{2}=0.920$.

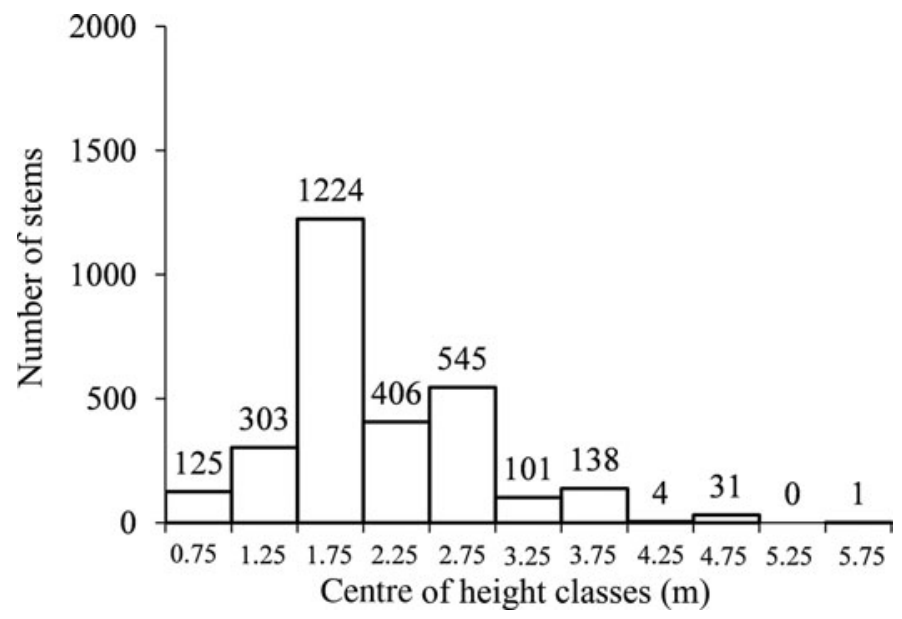

FIG. 5. Frequency distribution in height classes for vegetation on quartzite soils in Serra Negra, Rio Preto, Minas Gerais.

Plant List, 2013-), had no multistemmed individuals. Species with higher $I V$ also had a high percentage of multistemmed individuals (Table 2).

\section{Discussion}

Richness and diversity

The composition of most representative families sampled is close to that reported for the general flora of Serra Negra (Salimena et al., 2013), and also approximates the 
TABLE 2. Number of individuals, percentage of multistemmed individuals and total stems for the community and principal populations* in vegetation on quartzitic soils in Serra Negra, Rio Preto, Minas Gerais

\begin{tabular}{|c|c|c|c|}
\hline Species & No. of individuals & $\begin{array}{l}\text { Multistemmed } \\
\text { individuals (\%) }\end{array}$ & Total stems \\
\hline All 68 spp. sampled & 1899 & 28.33 & 2878 \\
\hline Eremanthus incanus & 543 & 19.34 & 701 \\
\hline Eremanthus erythropappus & 203 & 41.87 & 354 \\
\hline Eugenia modesta & 197 & 45.18 & 396 \\
\hline Byrsonima variabilis & 159 & 24.53 & 220 \\
\hline Trembleya parviflora & 113 & 30.97 & 168 \\
\hline Pseudobrickellia angustissima & 85 & 27.06 & 113 \\
\hline Aspidosperma olivaceum & 61 & 19.67 & 85 \\
\hline Erythroxylum amplifolium & 63 & 47.62 & 123 \\
\hline Ocotea tristis & 50 & 34.00 & 81 \\
\hline Myrcia pulchra & 37 & 43.24 & 90 \\
\hline Agarista glaberrima & 48 & 35.42 & 75 \\
\hline
\end{tabular}

${ }^{*}$ Ordered by decreasing importance value (see Table 1).

composition of forests in the region (Valente et al., 2011). The Myrtaceae, Asteraceae, Melastomataceae, Lauraceae and Primulaceae families are recognised as important in forest formations at altitude in the Atlantic Forest Domain (Oliveira-Filho \& Fontes, 2000). Therefore, in general, the floristic composition of woody vegetation on quartzite soils on Serra Negra tends to approach that of other woody formations in the region.

There have been no studies using similar methodology in similar physiognomies in the Atlantic Forest Domain, which prevents a direct comparison with this domain. However, the Shannon diversity and evenness values found were close to those found for the savanna (cerrado sensu stricto) area on quartzite soils in Piauí State, northern Brazil $\left(H^{\prime}, 2.75\right.$ nats/individual; $\left.J, 0.70\right)$, for which the same sampling methodology was applied (Lindoso et al., 2009). Species richness was also close to that determined by Lima et al. (2010) for some areas of rocky 'cerrado' in central Brazil, using the same sampling, although the $H^{\prime}$ values were slightly higher $\left(H^{\prime}, 3.09-3.65\right.$ nats/individual). These comparisons reveal a close structural affinity with the Brazilian savannas vegetation, which deserves future phytogeographical investigation.

\section{Phytosociology and vegetation structure}

The community showed a typical reverse $\mathbf{J}$ pattern of diameter class distribution. It can be inferred that the community has the potential to maintain its structure over time, with a good stock of young individuals able to occupy the places left by dead ones.

The two species of greatest ecological importance, Eremanthus incanus and $E$. erythropappus, which together comprise $33 \%$ of $I V$, are commonly known as 'candeias' and occur frequently in the rocky physiognomies of the Cerrado; they also occur in the Atlantic Forest Domain at altitudes above 700 m a.s.l. (Macleish, 1987). 
Ecological dominance is common in plant communities in habitats with more severe environmental conditions in the Atlantic Forest Domain (Scarano, 2002). In these environments, locally abundant species often play an important role in the operation and maintenance of communities (Scarano et al., 2001). In the present study, the strong dominance contrasts with the high species richness recorded in the area (Salimena et al., 2013). This is probably the result of limiting environmental factors, such as poor soil (Ribeiro, 2013), favouring species with adaptations to these conditions. Microhabitats in that environment and the proximity to other vegetation types (Menini Neto et al., 2009; Valente et al., 2011) allow the establishment of a large number of local rare species. Some of the species found were among the most important species recorded in forest formations adjacent to the study areas (Valente et al., 2011). Although these species have low densities and frequencies in campos rupestres, they are important species in forests in the Serra Negra. According to a study of forest formations at Serra Negra (Valente et al., 2011), Alchornea triplinervia (Spreng.) Müll.Arg., for example, is the species with the highest $I V$ in the Upper Montane Dense Rain Forest, and the species with the third highest $I V$ in the Alluvial Dense Rain Forest; and Eugenia widgrenii Sond. ex O.Berg. and Xylopia brasiliensis Spreng. are the species with the second and third highest $I V$ in the Montane Dense Rain Forest. This sharing of species between different vegetation types in the Serra Negra was also observed by Salimena et al. (2013). Sharing of species with forest formations seems to be a frequent pattern in grassland environments of mountains, where forest species tend to occur as occasional elements, showing smaller sizes, and often being more branched, because of limitations imposed by edaphic aspects (Messias et al., 2012; Oliveira-Filho et al., 2013; Valente et al., 2013).

The high percentage of multistemmed individuals shows that the formation of multiple stems is an important process in the structural conformation of this community. In open vegetation, competition for light is not an important factor, therefore plants can show more diverse forms, such as the formation of multistemmed individuals, in response to different selective pressures (Archibald \& Bond, 2003). Investment in forming multiple stems occurs at the expense of investment in other processes, especially the allocation of resources to reproduction (Iwasa \& Kubo, 1997). Furthermore, multistemmed plants tend to have lower biomass and shorter height than single-stemmed plants, being less competitive in shaded environments (Bond \& Midgley, 2001). However, sprouting and regrowth ability may have advantages as a way to recover after disturbances capable of causing loss of above-ground biomass, such as fire, strong winds and stem cut (Bond \& Midgley, 2001). Theoretical models show that sprouting is advantageous in situations in which the frequency and intensity of disturbance is intermediate to intense (Iwasa \& Kubo, 1997; Bellingham \& Sparrow, 2000).

The occurrence of high proportions of multistemmed individuals is not related only to the occurrence of disturbances in the environment. Dunphy et al. (2000), studying tropical dry forests in Puerto Rico, found a high proportion of multistemmed individuals and showed that in most cases they showed no signs of having been 
cut, keeping the main stem intact. Indeed, the model proposed by Bellingham \& Sparrow (2000) incorporates productivity of the environment as an important factor in predicting the rate of sprouting. In environments with low productivity, as in cases of low soil fertility, sprouting can be advantageous even without the presence of constant disturbances. Bellingham \& Sparrow (2009) found that, in tropical montane forests in Jamaica, the formation of multistemmed individuals is mainly related to low soil fertility. In the present study, it is likely that the high proportion of multistemmed individuals, especially among the most abundant species, is also related to low soil fertility (Olszevski et al., 2008).

\section{Final considerations and implications for conservation}

The results show that the woody vegetation on quartzite soils of Serra Negra is characterised by the contrast of strong ecological dominance and expressive richness, with elements of adjacent forests. In addition, three sampled species are considered endangered in the Atlantic Forest Domain of Minas Gerais State (Biodiversitas Foundation, 2008); Pseudobrickellia angustissima (Spreng. ex Baker) R.M.King \& H.Rob. and Verbesina pseudoclaussenii D.J.N.Hind (Asteraceae) are considered critically endangered, and Handroanthus albus (Cham.) Mattos (Bignoniaceae) is considered vulnerable. According to the Biodiversitas Foundation (2008), which used the criteria of the International Union for Conservation of Nature, these three species are considered endangered mainly because of factors related to their area of occupation and loss of habitat. Martinelli \& Moraes (2013) also point out that Verbesina pseudoclaussenii is critically endangered in Brazil and is now restricted to the Serra Negra.

The two most abundant species, Eremanthus incanus and E. erythropappus, have great economic importance in the region because of their highly durable wood, which is used mainly for making fences and for firewood extraction. Information from local residents indicates that they commonly use the wood for making fences and rustic furniture, and as fuel for wood stoves, but still with a low impact on natural populations. In Brazil, the commercial exploitation of 'candeias' for extraction of essential oil, which is used in dermatological products and the cosmetics industry (Bohlmann et al., 1980; Silvério et al., 2008), has been growing. The imminent exploitation of these species for oil extraction may pose an additional risk to the vegetation studied here, because the results show that these species have great ecological importance in the structural conformation of the woody community.

The great heterogeneity of vegetation, with many species of low frequency and locally 'rare', means that a strategy for their effective conservation must include the largest possible area distributed across the landscape. Strategies for flora conservation in the region should focus not only on the rare and endangered species, but also on locally abundant species that are functionally vital in maintaining the plant community (Scarano, 2002) and should also be considered in biodiversity conservation plans (Scarano 2009). Commercial use of woody species, if not performed in a planned way, 
can also increase soil exposure, which exposes the fragile structure and makes it subject to erosion (Olszevski et al., 2008). Therefore, a greater coordinated effort between the government and the local population is necessary to ensure the conservation and proper use of natural resources in the region.

\section{ACKNOWLEDGEMENTS}

We thank our colleagues at the herbarium Leopoldo Krieger (CESJ), Universidade Federal de Juiz de Fora, for their assistance in botanical identification; students of the Laboratory of Plant Ecology and Department of Botany, Universidade Federal de Juiz de Fora, especially Eduardo T. Amorim, for their help in fieldwork; researchers Dr João Marcelo Alvarenga Braga and Dr Luiz Menini Neto, and two anonymous reviewers, for their comments and suggestions; and the Postgraduate Programme in Ecology, Universidade Federal de Juiz de Fora, for logistical support. This work was supported by the Brazilian National Council of Technological and Scientific Development under grant no. 472921/2011-8 and master's scholarship for the first author.

\section{REFERENCES}

Alves, R., Silva, N., Oliveira, J. \& Medeiros, D. (2014). Circumscribing campo rupestre - megadiverse Brazilian rocky montane savanas. Brazil. J. Biol. 74(2): 355-362.

A mor im, E. T. (2013). Estudo florístico e ecológico das briófitas da Serra Negra (Minas Gerais) e sua relação com outras áreas do sudeste do Brasil. Master's thesis, Universidade Federal de Juiz de Fora.

Angiosperm Phylogeny Group (2009). An update of the Angiosperm Phylogeny Group classification for the orders and families of flowering plants: APG III. Bot. J. Linn. Soc. 161(2): 105-121.

ArChibALD, S. \& Bond, W. J. (2003). Growing tall vs growing wide: tree architecture and allometry of Acacia karroo in forest, savanna, and arid environments. Oikos 102(1):3-14.

Bellingham, P. J. \& Sparrow, A. D. (2000). Resprouting as a life history strategy in woody plant communities. Oikos 89(2): 409-416.

Bellingham, P. J. \& S PARRow, A. D. (2009). Multistemmed trees in montane rain forests: their frequency and demography in relation to elevation, soil nutrients and disturbance. J. Ecol. 97(3): 472-483.

Benites, V. M., Schaefer, C. E., Simas, F. N. B. \& Santos, H. G. (2007). Soils associated with rock outcrops in the Brazilian mountain ranges Mantiqueira and Espinhaço. Revista Brasil. Bot. 30(4): 569-577.

Biodiversitas Foundation (2008). Revisão das Listas das Espécies da Flora e da Fauna Ameçadas de Extinção do Estado de Minas Gerais. Online. Available: http://www.biodiversitas.org.br/listas-mg (accessed 9 March 2015).

Bohlmann, F., Zdero, C., King, R. M. \& Robinson, H. (1980). Sesquiterpene lactones from Eremanthus species. Phytochemistry 19(12): 2663-2668.

BOND, W. J. \& MidGLEY, J. J. (2001). Ecology of sprouting in woody plants: the persistence niche. Trends Ecol. Evol. 16(1): 45-51.

Conceição, A. A, Rapini, A., Carmo, F. F, Brito, J. C., Silla, G. A, Neves, P. S. \& J АСОВ I, C. M. (2016). Rupestrian Grassland vegetation, diversity, and origin. In: Fernandes, G. W. (ed.) Ecology and Conservation of Mountaintop Grasslands in Brazil, pp. 105-127. Cham: Springer. 
Dunphy, B. K., Murphy, P. G. \& Lugo, A. E. (2000). The tendency for trees to be multiple-stemmed in tropical and subtropical dry forests: studies of Guanica forest, Puerto Rico. Trop. Ecol. 41(2): 161-167.

Eiten, G. (1979). Formas fisionômicas do Cerrado. Revista Brasil. Bot. 2: 139-148.

EM ATER (2003). Projeto APA Serra do Funil. Rio Preto: Empresa de Assistência Técnica e Extensão Rural do Estado de Minas Gerais.

Felfili, J. M. \& Resende, R. P. (2003). Conceitos e Métodos em Fitossociologia. Brasília: Departamento de Engenharia Florestal, Universidade Federal de Brasília.

Felfili, J. M., Carvalho, F. A. \& Haidar, R. F. (2005). Manual para o Monitoramento de Parcelas Permanentes nos Biomas Cerrado e Pantanal. Brasília: Universidade de Brasília.

Fernandes, G. W. (2016). The megadiverse Rupestrian Grassland. In: Fer nandes, G. W. (ed.) Ecology and Conservation of Mountaintop Grasslands in Brazil, pp. 3-14. Cham: Springer.

Ha m mer, Ø. (2011). PAST. PAleontological STatistics. Reference Manual, version 2.08. Online. Available: http://nhm2.uio.no/norlex/past/doc1.html (accessed 11 March 2015).

Heilbron, M., Tupinambá, M., Eirado, L. G., Ribeiro, A., Paciullo, F. V. P., Trouw, R. A., Valeriano, C. M., Junho, M. C. B., Roig, H. L., Nogueira, J. R., Medeiros, R. M., Rocha, D., Polonia, J., Silva, R. R. \& Toledo, C. (2000). Geologia das folhas Santa Rita do Jacutinga e Rio Preto. Rio de Janeiro: COMIG-UFMG-UFRJ-UERJ.

I B GE (2012). Manual Técnico da Vegetação Brasileira, 2nd edition. Rio de Janeiro: Instituto Brasileiro de Geografia e Estatística.

IwASA, Y. \& Ku во, T. (1997). Optimal size of storage for recovery after unpredictable disturbances. Evol. Ecol. 11(1): 41-65.

Kent, M. \& Coker, P. (1992). Vegetation Description and Data Analysis: a Practical Approach. London: John Wiley \& Sons.

Lima, T. A., Pinto, J. R. R., Lenza, E. \& Pinto, A. S. (2010). Florística e estrutura da vegetação arbustivo-arbórea em uma área de cerrado rupestre no Parque Estadual da Serra de Caldas Novas, Goiás. Biota Neotrop. 10(2): 159-166.

Lindoso, G. S., Felfili, J. M., Costa, J. M. \& Castro, A. A. J. F. (2009). Diversidade e estrutura do cerrado sensu stricto sobre areia (Neossolo Quartzarênico) na Chapada Grande Meridional, Piauí. Revista Biol. Neotrop. 6(2): 45-61.

Macleish, N. F. F. (1987). Revision of Eremanthus (Compositae: Vernonieae). Ann. Missouri Bot. Gard. 74(2): 265-290.

Magur Ran, A. E. (2004). Measuring Biological Diversity. Oxford: Blackwell Science.

Martinelli, G. (2007). Mountain biodiversity in Brazil. Revista Brasil. Bot. 30(4): $587-597$.

Martinelli, G. \& Moraes, M. A. (eds) (2013). Livro Vermelho da Flora do Brasil. Rio de Janeiro: Centro Nacional de Conservação da Flora.

Menini Neto, L., Matozinhos, C. N., Abreu, N. L., Valente, A. S. M., Antunes, K., Souza, F. S., Viana, P. L. \& Salimena, F. R. G. (2009). Flora vascular não-arbórea de uma floresta de grota na Serra da Mantiqueira, Zona da Mata de Minas Gerais, Brasil. Biota Neotrop. 9(4): 149-161.

Messias, M. C. T. B., Leite, M. G. P., Meira-Neto, J. A. A. \& Kozovits, A. R. (2012). Fitossociologia de campos rupestres quartzíticos e ferruginosos no Quadrilátero Ferrífero, Minas Gerais. Acta Bot. Brasil. 26(1): 230-242.

Oliveira, C. S. \& Marques-Neto, R. (2014). Geoecological characterization and interpretation of the landscape at Serra Negra and Serra das Três Cruzes - MG. Cad. Geogr. 24(1): $27-41$. 
Oliveira-Filho, A. T. (2009). Classificação das fitofisionomias da América do Sul cisandina tropical e subtropical: proposta de um novo sistema - prático e flexível - ou uma injeção a mais de caos? Rodriguésia 60(2): 237-258.

Oliveira-Filho, A. T. \& Fontes, M. A. L. (2000). Patterns of floristic differentiation among Atlantic Forests in Southeastern Brazil and the influence of climate. Biotropica 32(4): 793-810.

Oliveira-Filho, A., Fontes, M. A. L., Viana, P. L., Valente, A. S., Salimena, F. R. G. \& Ferreira, F. M. (2013). O mosaico de fitofisionomias do Parque Estadual do Ibitipoca. In: Forzza, R. C., Menini Neto, L., Salimena, F. R. G. \& ZA P P I, D. (eds) Flora do Parque Estadual do Ibitipoca e Seu Entorno, pp. 53-93. Juiz de Fora: Editora UFJF.

Olszevsie N., Costa, L. M., Fernandes-Filho, E. I. \& Costa, O. D. V. (2008). Paisagem e uso da terra em diferentes unidades geológicas em área sob influência do Rio Preto (MG-RJ). Revista Biol. Ci. Terra 8(2): 45-59.

Peel, M. C., Finlayson, B. L. \& Mcmahon, T. A. (2007). Updated world map of the Köppen-Geiger climate classification. Hydrol. Earth Syst. Sci. 11: 1633-1644.

Plant List (2013-). Version 1.1. Online. Available: http://www.theplantlist.org/ (accessed 28 October 2016).

Ribeiro, J. H. C. (2013). A vegetação lenhosa sobre solos quartzíticos na Serra Negra (Rio Preto, MG): estrutura, diversidade e gradientes ambientais. Master's thesis, Universidade Federal de Juiz de Fora.

Ribeiro, K. T., Opazo, B. M. M. \& Scarano, F. R . (2007). Species composition and biogeographic relations of the rock outcrop flora on the high plateau of Itatiaia, SE-Brazil. Revista Brasil. Bot. 30(4): 623-639.

Rio de Janeiro Botanical Garden (continuously updated). Flora do Brasil 2020. Online. Available: http://floradobrasil.jbrj.gov.br (accessed 10 April 2016).

Salimena, F. R. G., Matozinhos, C. N., Abreu, N. L., Souza, F. S., Ribeiro, J. H. C. \& Menini-Neto, L. (2013). Flora fanerogâmica da Serra Negra, Minas Gerais, Brasil. Rodriguésia 64(2): 311-320.

SCARA N , F. R . (2002). Structure, function and floristic relationships of plant communities in stressful habitats marginal to the Brazilian Atlantic rainforest. Ann. Bot. 90(4): 517-524.

SCARA No, F. R . (2009). Plant communities at the periphery of the Atlantic rain forest: rare-species bias and its risks for conservation. Biol. Conservation 142(6): 1201-1208.

Scarano, F. R., Duarte, H. M., Ribeiro, K. T., Rodrigues, P. J. F. P., Barcellos, E. M. B., Franco, A. C., Brulfert, J., Deléens, E. \& Lüttge, U. (2001). Four sites with contrasting environmental stress in southeastern Brazil: relations of species, life form diversity, and geographic distribution to ecophysiological parameters.

Bot. J. Linn. Soc. 136(4): 345-364.

Silvério, M. S., Sousa, O. V., Del-Vechio-Vieira, G., Miranda, M. A., Matheus, F. C. \& Ka plan, M. A. C. (2008). Propriedades farmacológicas do extrato etanólico de Eremanthus erythropappus (DC.) McLeish (Asteraceae). Revista Brasil. Farmacogn. 18(3): 430-435.

Souza, F. S., Salino, A., Viana, P. L. \& Salimena, F. R. G. (2012). Pteridófitas da Serra Negra, Minas Gerais, Brasil. Acta Bot. Brasil. 26(2): 378-390.

Thier s, B. (continuously updated). Index Herbariorum: a Global Directory of Public Herbaria and Associated Staff. New York Botanical Garden's Virtual Herbarium. Online. Available: http://sweetgum.nybg.org/science/ih/ (accessed 10 April 2016).

Uagoda, R., Avelar, A. \& Netto, A. L. C. (2011). Karstic morphology control in non-carbonate rocks: Santana basin, middle Paraiba do Sul river valley, Brazil. $Z$. Geomorph. 55(1): 1-13. 
Valente, A. S. M., Garcia, P. O., Salimena, F. R. G. \& Oliveira-Filho, A. T. (2011). Composição, estrutura e similaridade florística da Floresta Atlântica, na Serra Negra, Rio Preto - MG. Rodriguésia 62(2): 321-340.

Valente, A. S. M., Araújo, F. S., Fontes, M. A. L. \& Rocha, G. C. (2013). O entorno do Parque Estadual do Ibitipoca: fitofisionmias e lista florística. In: For z ZA, R. C., Menini Neto, L., Salimena, F. R. G., Za p pi, D. (eds) Flora do Parque Estadual do Ibitipoca e seu Entorno, pp. 293-329. Juiz de Fora: Editora UFJF.

VASCONCELOS, M. F. (2011). O que são campos rupestres e campos de altitude nos topos de montanha do Leste do Brasil? Revista Brasil. Bot. 34(2): 241-246.

Whittaker, R. J., Willis, K. J. \& Field, R. (2001). Scale and species richness: towards a general, hierarchical theory of species diversity. J. Biogeogr. 28(4): 453-470.

\section{Received 16 May 2016; accepted for publication 18 October 2016; first published online 15 December 2016}

\section{APPENDIX}

The testimony material (Appendix table 1) is deposited in the herbarium Leopoldo Krieger (CESJ) and the Laboratory of Plant Ecology, Department of Botany, Universidade Federal de Juiz de Fora.

A pPendix table 1. Species sampled in vegetation on quartzitic soils in Serra Negra, Rio Preto, Minas Gerais, arranged in alphabetical order of family, genus and species, respectively

Species sampled* ${ }^{*}$ Testimony material

Anacardiaceae

Tapirira obtusa (Benth.) J.D.Mitch.

Ribeiro 120

Annonaceae

Guatteria australis A.St.-Hil.

Ribeiro 119

Xylopia brasiliensis Spreng.

Ribeiro 104

Apocynaceae

Aspidosperma olivaceum Müll.Arg.

Ribeiro 245

Aquifoliaceae

Ilex subcordata Reissek

Ribeiro 107

Asteraceae

Calea sp.

Eremanthus erythropappus (DC.) MacLeish

Ribeiro 229

Eremanthus incanus (Less.) Less.

Ribeiro 103

Pseudobrickellia angustissima (Spreng. ex Baker) R.M.King \& H.Rob.

Verbesina pseudoclaussenii D.J.N.Hind

Ribeiro 106

Bignoniaceae

Handroanthus albus (Cham.) Mattos

Ribeiro 105

Ribeiro 116

Celastraceae

Maytenus urbaniana Loes.

Ribeiro 114

Clethraceae

Clethra scabra Pers.

Ribeiro 124

Clusiaceae

Clusia criuva Cambess.

Ribeiro 115

Ribeiro 135 
Appendix table 1. (Continued)

\begin{tabular}{|c|c|}
\hline Species sampled* & Testimony material \\
\hline \multicolumn{2}{|l|}{ Cunoniaceae } \\
\hline Lamanonia cuneata (Cambess.) Kuntze & Ribeiro 125 \\
\hline \multicolumn{2}{|l|}{ Ericaceae } \\
\hline Agarista glaberrima (Sleumer) Judd & Ribeiro 134 \\
\hline Gaylussacia densa Cham. & Ribeiro 132 \\
\hline \multicolumn{2}{|l|}{ Erythroxylaceae } \\
\hline $\begin{array}{l}\text { Erythroxylum amplifolium (Mart.) O.E.Schulz } \\
\text { (= Erythroxylum amplifolium Baill.) }\end{array}$ & Ribeiro 137 \\
\hline \multicolumn{2}{|l|}{ Euphorbiaceae } \\
\hline $\begin{array}{l}\text { Alchornea triplinervia (Spreng.) Müll.Arg. } \\
\text { Maprounea guianensis Aubl. }\end{array}$ & Ribeiro 109 \\
\hline \multicolumn{2}{|l|}{ Fabaceae } \\
\hline Chamaecrista cathartica (Mart.) H.S.Irwin \& Barneby & Ribeiro 110 \\
\hline Fabaceae sp. 1 & Ribeiro 138 \\
\hline \multicolumn{2}{|l|}{ Hypericaceae } \\
\hline Vismia magnoliifolia Cham. \& Schltdl. & Ribeiro 140 \\
\hline $\begin{array}{l}\text { Vismia parviflora Cham. \& Schltdl. } \\
\text { (= Vismia parviflora } \text { Schltdl. \& Cham.) }\end{array}$ & Ribeiro 141 \\
\hline \multicolumn{2}{|l|}{ Lamiaceae } \\
\hline Hyptis monticola Mart. ex Benth. & Ribeiro 143 \\
\hline Vitex sellowiana Cham. & Ribeiro 144 \\
\hline \multicolumn{2}{|l|}{ Lauraceae } \\
\hline Lauraceae sp. 1 & Ribeiro 121 \\
\hline Ocotea tristis (Nees \& Mart.) Mez & Ribeiro 147 \\
\hline $\begin{array}{l}\text { Persea rufotomentosa Nees \& Mart. } \\
\quad(=\text { Persea rufotomentosa Nees \& C.Mart.) }\end{array}$ & Ribeiro 145 \\
\hline Persea willdenovii Kosterm. & Ribeiro 126 \\
\hline \multicolumn{2}{|l|}{ Malpighiaceae } \\
\hline Byrsonima variabilis A.Juss. & Ribeiro 123 \\
\hline \multicolumn{2}{|l|}{ Malvaceae } \\
\hline Pavonia viscosa A.St.-Hil. & Ribeiro 131 \\
\hline \multicolumn{2}{|l|}{ Melastomataceae } \\
\hline Miconia sp. 1 & Ribeiro 127 \\
\hline Miconia urophylla DC. & Ribeiro 146 \\
\hline Tibouchina estrellensis (Raddi) Cogn. & Ribeiro 130 \\
\hline $\begin{array}{l}\text { Tibouchina fissinervia (Schrank \& Mart. ex DC.) } \\
\text { Cogn. (= Tibouchina fissinervia Cogn.) }\end{array}$ & Ribeiro 150 \\
\hline Trembleya parviflora (D.Don) Cogn. & Ribeiro 151 \\
\hline \multicolumn{2}{|l|}{ Meliaceae } \\
\hline Cabralea canjerana (Vell.) Mart. & Ribeiro 157 \\
\hline \multicolumn{2}{|l|}{ Monimiaceae } \\
\hline Macropeplus schwackeanus (Perkins) I.Santos \& Peixoto & Ribeiro 158 \\
\hline \multicolumn{2}{|l|}{ Myrtaceae } \\
\hline Blepharocalyx salicifolius (Kunth) O.Berg & Ribeiro 152 \\
\hline Eugenia sp. 1 & Ribeiro 159 \\
\hline Eugenia sp. 2 & Ribeiro 156 \\
\hline
\end{tabular}


Appendix TABLE 1. (Continued)

\begin{tabular}{ll}
\hline \hline Species sampled* & Testimony material \\
\hline Eugenia bimarginata DC. & \\
Eugenia modesta DC. & Ribeiro 162 \\
Eugenia handroana D.Legrand & Ribeiro 174 \\
Eugenia involucrata DC. & Ribeiro 164 \\
Eugenia widgrenii Sond. ex O.Berg & Ribeiro 175 \\
Myrcia guianensis (Aubl.) DC. & Ribeiro 161 \\
Myrcia hartwegiana (O.Berg) Kiaersk. & Ribeiro 187 \\
Myrcia mutabilis (O.Berg) N.Silveira & Ribeiro 192 \\
Myrcia pulchra (O.Berg) Kiaersk. & Ribeiro 190 \\
Myrcia splendens (Sw.) DC. & Ribeiro 176 \\
Myrcia venulosa DC. & Ribeiro 163 \\
Myrtaceae sp. 1 & Ribeiro 160 \\
Psidium firmum O.Berg & Ribeiro 179 \\
Ochnaceae & \\
Ouratea semiserrata (Mart. \& Nees) Engl. & Ribeiro 177 \\
Pentaphylacaceae & \\
Ternstroemia brasiliensis Cambess. & Ribeiro 167 \\
Peraceae & \\
Pera glabrata (Schott) Poepp. ex Baill. & Ribeiro 166 \\
Phytolaccaceae & \\
Seguieria sp. & Ribeiro 183 \\
Primulaceae & \\
Myrsine gardneriana A.DC. & Ribeiro 195 \\
Myrsine lancifolia Mart. & Ribeiro 184 \\
Myrsine sp. 1 & Ribeiro 165 \\
Myrsine umbellata Mart. & Ribeiro 170 \\
Rubiaceae & \\
Ladenbergia hexandra (Pohl) Klotzsch & Ribeiro 185 \\
Remijia ferruginea (A.St.-Hil.) DC. & Ribeiro 186 \\
Sapindaceae & \\
Cupania ludowigii Somner \& Ferrucci & Ribeiro 168 \\
Matayba marginata Radlk. & Ribeiro 173 \\
Undetermined & \\
Undetermined sp. 1 & Ribeiro 122 \\
\hline \hline Speces & \\
\hline &
\end{tabular}

* Species names are those listed in Flora do Brasil 2020 (Rio de Janeiro Botanical Garden, continuously updated); Plant List (2013-) names are in parentheses. 